Supporting Information

\title{
Detecting Basal Myeloperoxidase Activity in Living Systems with a Near-Infrared Emissive "Turn-On" Probe
}

Lingyan Liu, ${ }^{\text {a }}$ Peng Wei, ${ }^{\text {b }}$ Wei Yuan, ${ }^{a}$ Zhongkuan Liu, ${ }^{\text {a }}$ Fengfeng Xue, ${ }^{a}$ Xinyu Zhang ${ }^{\mathrm{c}}$ and Tao Yi*a,b

a Department of Chemistry, Fudan University, 2005 Songhu Road, Shanghai 200433,

China, E-mail: yitao@fudan.edu.cn

${ }^{b}$ College of Chemistry, Chemical Engineering and Biotechnology, Donghua University,

Shanghai 201620, China, E-mail: weipeng@dhu.edu.cn

' School of Public Health, Hongqiao International Institute of Medicine, Shanghai Jiao

Tong University School of Medicine, Shanghai 200025, China

\section{Content}

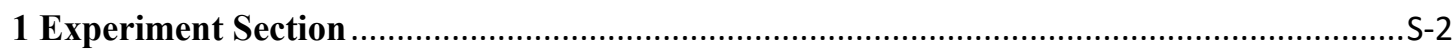

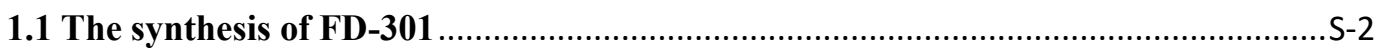

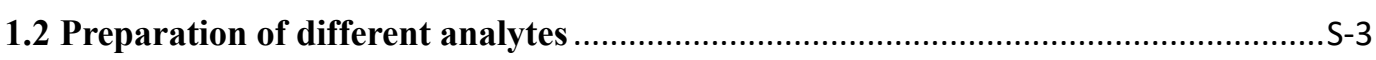

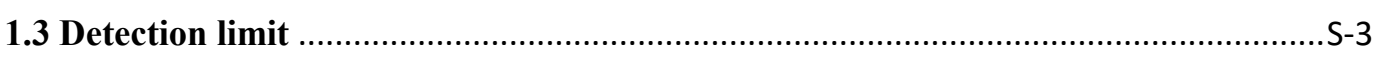

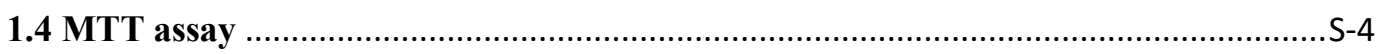

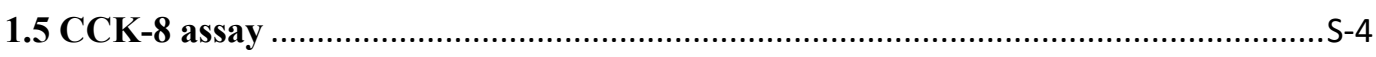

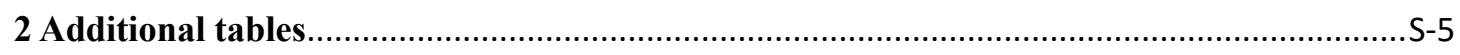

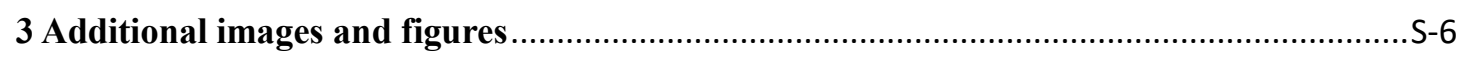

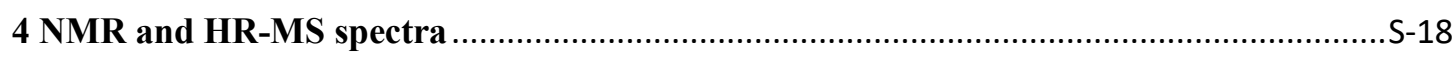

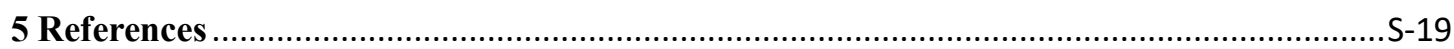




\section{Experiment Section}

\subsection{The synthesis of FD-301}

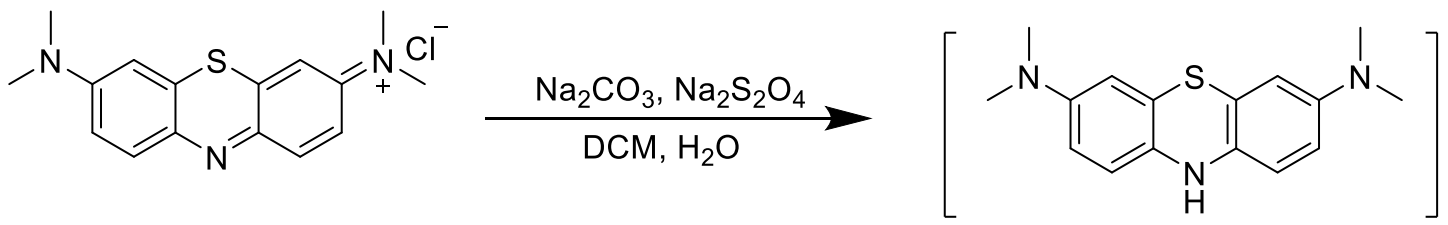<smiles>CN(C)c1ccc(C(=O)NNC(=O)N2c3ccc(N(C)C)cc3Sc3cc(N(C)C)ccc32)cc1</smiles>

Scheme S1. Synthetic route of FD-301.

FDOCl-2 was synthsized according to our published report. ${ }^{1}$ Then, 4 -ABAH $(0.18$ $\mathrm{g}, 1.2 \mathrm{mmol}, 1.0 \mathrm{eq})$ were dissolved in $5 \mathrm{~mL}$ of dichloromethane, triethylamine $(0.36 \mathrm{~g}$, $3.6 \mathrm{mmol}, 3.0 \mathrm{eq})$ was added dropwise, finally FDOCl-2 (0.5 g, $1.44 \mathrm{mmol}, 1.2 \mathrm{eq})$ was added rapidly, and the resulting mixture was stirred in an ice-water bath until the reaction completed as indicated by TLC analysis which was conducted at $1 \mathrm{~h}$ intervals.

The reaction mixture was poured into $200 \mathrm{~mL}$ of ice-water while stirring, and was extracted with $3 \times 100 \mathrm{~mL}$ portions of ethyl acetate. The combined extracts were washed with brine, dried over anhydrous sodium sulfate and evaporated on a rotary evaporator to afford a solid residue, which was purified by column chromatography (ethyl acetate/petroleum ether $=1 / 5$ ) to yield FD-301 as a light green solid. Yield $0.1 \mathrm{~g}$, 55\%. ${ }^{1} \mathrm{H}$ NMR (400 MHz, DMSO- $\left.d_{6}\right) \delta 9.75(\mathrm{~s}, 1 \mathrm{H}), 7.92(\mathrm{~s}, 1 \mathrm{H}), 7.58(\mathrm{~d}, J=7.6 \mathrm{~Hz}$, 2H), $7.42(\mathrm{~d}, J=8.8 \mathrm{~Hz}, 2 \mathrm{H}), 6.72-6.67(\mathrm{~m}, 4 \mathrm{H}), 6.53(\mathrm{~d}, J=7.2 \mathrm{~Hz}, 2 \mathrm{H}), 5.69(\mathrm{~s}, 2 \mathrm{H})$, $2.89(\mathrm{~s}, 12 \mathrm{H}) .{ }^{13} \mathrm{C}$ NMR $\left(100 \mathrm{MHz}, \mathrm{DMSO}-d_{6}\right) \delta 166.04,155.21,152.07,148.61$, 132.85, 129.03, 128.01, 126.95, 119.1, 112.53, 111.29, 110.31, 40.25. HR-MS (ESI): $[\mathrm{M}+\mathrm{H}]^{+}$calcd for $\mathrm{C}_{24} \mathrm{H}_{26} \mathrm{~N}_{6} \mathrm{O}_{2} \mathrm{~S}: 463.1871$; found: 463.1911 . 


\subsection{Preparation of different analytes}

Different analysts were prepared according to our published methods. ${ }^{1}$ $\mathrm{HOCl}$ was obtained from $14.5 \% \mathrm{NaOCl}$ solution

Other ROS/RNS $(20-100 \mu \mathrm{M})$ were prepared in $\mathrm{ddH}_{2} \mathrm{O}$ as follows:

$\mathrm{H}_{2} \mathrm{O}_{2}$ was diluted from a $30 \%$ solution.

- $\mathrm{OH}$ (Hydroxyl radical) was generated by Fenton reaction. To generate $\bullet \mathrm{OH}, \mathrm{H}_{2} \mathrm{O}_{2}$ was added in the presence of 10 equiv. of ferrous chloride. The concentration of $\bullet \mathrm{OH}$ was equal to the $\mathrm{H}_{2} \mathrm{O}_{2}$ concentration.

TBHP (tert-butyl hydroperoxide) was obtained from 70\% TBHP solution in $\mathrm{ddH}_{2} \mathrm{O}$.

ROO• was prepared by dissolving 2,2'-Azobis(2-amidinopropane)dihydrochlo ride in $\mathrm{ddH}_{2} \mathrm{O}$.

NO was prepared by dissolving SNP (Sodium Nitroferricyanide (III) Dihydrate) in $\mathrm{ddH}_{2} \mathrm{O}$.

$\mathrm{O}_{2}^{-}$was prepared by dissolving $\mathrm{KO}_{2}$ (Potassium superoxide) in DMSO.

$\mathrm{ONOO}^{-}$was prepared using 3-morpholinosydnonimine hydrochloride.

$t$-BuOO was prepared by adding TBHP in the presence of 10 equiv. of ferrous chloride. The concentration of $t$-BuOO was equal to the TBHP concentration.

Other analytes were prepared in $\mathrm{ddH}_{2} \mathrm{O}$.

Unless otherwise noted, for all fluorescent measurements, the excitation wavelength was $620 \mathrm{~nm}$ and the emission wavelength was collected from 640 to 830 nm.

\subsection{Detection limit}

The detection limit $(3 \sigma / k)$ was calculated based on the linear relationship between the fluorescence intensity at $686 \mathrm{~nm}$ and the concentration of $\mathrm{HOCl}$ or MPO. $\sigma$ is the standard deviation of the blank measurement $(n=12)$ and $k$ is the slope of the fluorescence intensity versus $\mathrm{HOCl}$ concentration. 


\subsection{MTT assay}

The methyl thiazolyl tetrazolium (MTT) assay was used to detect the cytotoxicity of FD-301. RAW264.7 macrophages were seeded in 96-well plates at a density of $1 \times 10^{4}$ cells per well, then cultured in $5 \% \mathrm{CO}_{2}$ at $37^{\circ} \mathrm{C}$ for $24 \mathrm{~h}$. After the cells were incubated with FD-301 at different concentrations $(0,5,10,20$, and $50 \mu \mathrm{M}$ in DMSO/cell culture medium with 10\% FBS = 1: 49) for 12 and $24 \mathrm{~h}$, respectively, MTT $(20 \mu \mathrm{L}, 5 \mathrm{mg} / \mathrm{mL})$ was added to each well of the 96-well assay plate for $4 \mathrm{~h}$ at $37^{\circ} \mathrm{C}$. After dimethyl sulfoxide (DMSO, $200 \mu \mathrm{L} /$ well) was added, the absorbance was measured at $490 \mathrm{~nm}$ using a microplate reader. All samples were analyzed in triplicate.

\subsection{CCK-8 assay}

A cell counting kit-8 (CCK-8) was employed in this experiment to quantitatively evaluate the HL-60 cell viability. HL-60 cells were seeded in 96-well plates at a density of $1 \times 10^{4}$ cells per well, then cultured in $5 \% \mathrm{CO}_{2}$ at $37^{\circ} \mathrm{C}$ for $24 \mathrm{~h}$. After the cells were incubated with FD-301 at different concentrations $(0,5,10,15$, and $20 \mu \mathrm{M}$ in $\mathrm{DMSO} /$ cell culture medium with $10 \% \mathrm{FBS}=1: 149$ ) for 6 and $12 \mathrm{~h}$, respectively, $100 \mu \mathrm{L}$ DMEM containing $10 \%$ CCK-8 was added to each well of the 96-well assay plate for $4 \mathrm{~h}$ at $37{ }^{\circ} \mathrm{C}$, six parallel replicates were prepared. The absorbance at 450 was determined using a microplate reader (Bio Tek Instruments, Inc). All samples were analyzed in triplicate. 


\section{Additional tables}

Table S1 Some published indirect methods for measuring MPO activity ${ }^{a}$

\begin{tabular}{|c|c|c|c|c|c|c|}
\hline $\begin{array}{c}\text { Detection } \\
\text { mechanisms }\end{array}$ & Probes & $\begin{array}{c}\text { Detection time } \\
\left(\mathrm{MPO} / \mathrm{H}_{2} \mathrm{O}_{2} / \mathrm{Cl}^{-} \text {system) }\right.\end{array}$ & Sensitivity ${ }^{b}$ & Selectivity ${ }^{c}$ & Application & Literature \\
\hline \multirow{3}{*}{$\begin{array}{l}\text { Luminol } \\
\text { bioluminescence }\end{array}$} & MAPS & Under an hour & -- & -- & $\begin{array}{c}\text { Plasma samples from } \\
\text { patients with } \\
\text { cardiovascular disease }\end{array}$ & 2 \\
\hline & $\begin{array}{c}\text { Luminol- } \\
\text { BLI } \\
\end{array}$ & $20-25 \min$ & -- & -- & $\begin{array}{c}\text { Mice whole blood/gene } \\
\text { knockout mice }\end{array}$ & 3 \\
\hline & Luminol-R & $6 \mathrm{~min}$ & -- & -- & $\begin{array}{l}\text { Neutrophil/ inflamed mice } \\
\text { lungs/ tumor metastases }\end{array}$ & 4 \\
\hline \multirow{4}{*}{$\begin{array}{l}\text { Reaction with } \\
\mathrm{HOCl}\end{array}$} & Cy7-NphS & $\sim 500 \mathrm{~s}$ & $\begin{array}{c}\sim 6 \text {-fold }(1.28 \\
\text { equiv) }\end{array}$ & $\begin{array}{c}\text { >5-fold } \\
\left(15 \mu \mathrm{M} \mathrm{HOCl} / 100 \mu \mathrm{M} \mathrm{H}_{2} \mathrm{O}_{2}\right)\end{array}$ & HL-60 cells & 5 \\
\hline & CY-FPA & $\begin{array}{c}2 \mathrm{~min} \\
\text { (fluorescence quenching) }\end{array}$ & $\begin{array}{l}\text { 10-fold quenching } \\
\text { (3 equiv) }\end{array}$ & $\begin{array}{c}\text { 10-fold } \\
\left(9 \mu \mathrm{M} \mathrm{HOCl} / 300 \mu \mathrm{M} \mathrm{H}_{2} \mathrm{O}_{2}\right)\end{array}$ & A549 cells & 6 \\
\hline & SNAPF & $\sim 30 \mathrm{~min}$ & $\begin{array}{l}\text { 8-fold (with } \\
\text { excess } \mathrm{HOCl} \text { ) }\end{array}$ & $\begin{array}{c}\text { 8-fold } \\
\left(10 \mu \mathrm{M} \mathrm{HOCl} / 100 \mu \mathrm{M} \mathrm{H}_{2} \mathrm{O}_{2}\right)\end{array}$ & $\begin{array}{l}\text { Human neutrophils/ } \\
\text { peritonitis mice/ human } \\
\text { Atherosclerotic Plaque }\end{array}$ & 7 \\
\hline & FD-301 & $<10 \min$ & $\begin{array}{l}\sim 130 \text {-fold ( } 3 \\
\text { equiv) }\end{array}$ & $\begin{array}{c}>18 \text {-fold } \\
\left(5 \mu \mathrm{M} \mathrm{HOCl} / 20 \mu \mathrm{M} \mathrm{ONOO}^{-}\right)\end{array}$ & $\begin{array}{l}\text { HL-60 cells/ RAW cells / } \\
\text { acute arthritis and } \\
\text { ulcerative colitis mice } \\
\text { models }\end{array}$ & $\begin{array}{l}\text { This } \\
\text { article }\end{array}$ \\
\hline
\end{tabular}

${ }^{a}$ If no actual data were provided in the references, data were estimated according to the original published Figureures.

${ }^{b}$ Fluorescence intensity or emission ratio changes before and after treated with $\mathrm{HOCl}$.

${ }^{c}$ Fluorescence intensity or emission ratio changes before and after treated with $\mathrm{HOCl}$. 
Table S2 Fluorescence responses and absorbance changes of FD-301 $(5 \mu \mathrm{M})$ toward different concentrations of $\mathrm{HOCl}$

\begin{tabular}{ccc}
\hline Concentration $(\boldsymbol{\mu M})$ & Absorbance & Fluorescence Intensity \\
\hline 0 & 0.006 & 123 \\
5 & 0.074 & 3731 \\
10 & - & 8842 \\
15 & 0.205 & 15490 \\
20 & - & 17420 \\
\hline
\end{tabular}

Table S3 Fluorescence responses and absorbance changes of FD-301 $(5 \mu \mathrm{M})$ toward various ROS/RNS

\begin{tabular}{|c|c|c|c|}
\hline $\mathbf{R O S} / \mathbf{R N S}$ & Concentration $(\boldsymbol{\mu M})$ & Absorbance & Fluorescence Intensity \\
\hline $\mathrm{H}_{2} \mathrm{O}_{2}$ & 20 & $<0.008$ & $<190$ \\
\hline $\mathrm{O}_{2}^{-}$ & 20 & $<0.008$ & $<190$ \\
\hline $\mathrm{TBHP}$ & 20 & $<0.008$ & $<210$ \\
\hline${ }^{\circ} \mathrm{OH}$ & 20 & 0.014 & $<190$ \\
\hline $\mathrm{NO}$ & 20 & $<0.008$ & $<190$ \\
\hline $\mathrm{ONOO}^{-}$ & 20 & $<0.008$ & $<190$ \\
\hline $\mathrm{ROO}^{\cdot}$ & 20 & $<0.008$ & $<190$ \\
\hline$t$-BuOO & 20 & 0.013 & $<300$ \\
\hline $\mathrm{HOCl}$ & 5 & 0.073 & $>3200$ \\
\hline
\end{tabular}

Table S4 Clinically evaluated for mice model

\begin{tabular}{|c|c|c|c|}
\hline Group & Weight loss & Stool consistency & Bleeding \\
\hline Blank & None & Normal stool & No bleeding \\
\hline UC & $>20 \%$ & Watery stool & Gross bleeding \\
\hline $\begin{array}{c}\text { UC } \\
+ \\
\text { Inhibitor }\end{array}$ & $\begin{array}{c}>20 \% \text { (8 days before) } \\
\text { Gradually normal (next } \\
9 \text { days) }\end{array}$ & $\begin{array}{l}\text { Watery stool ( } 8 \text { days } \\
\text { before) } \\
\text { Normal stool (next } \\
9 \text { days) }\end{array}$ & $\begin{array}{c}\text { Gross bleeding ( } 8 \text { days } \\
\text { before) } \\
\text { No bleeding (next } 9 \\
\text { days) }\end{array}$ \\
\hline
\end{tabular}

It is important to note that animal weights and stool are not subjective to interpretation.

\section{Additional images and figures}



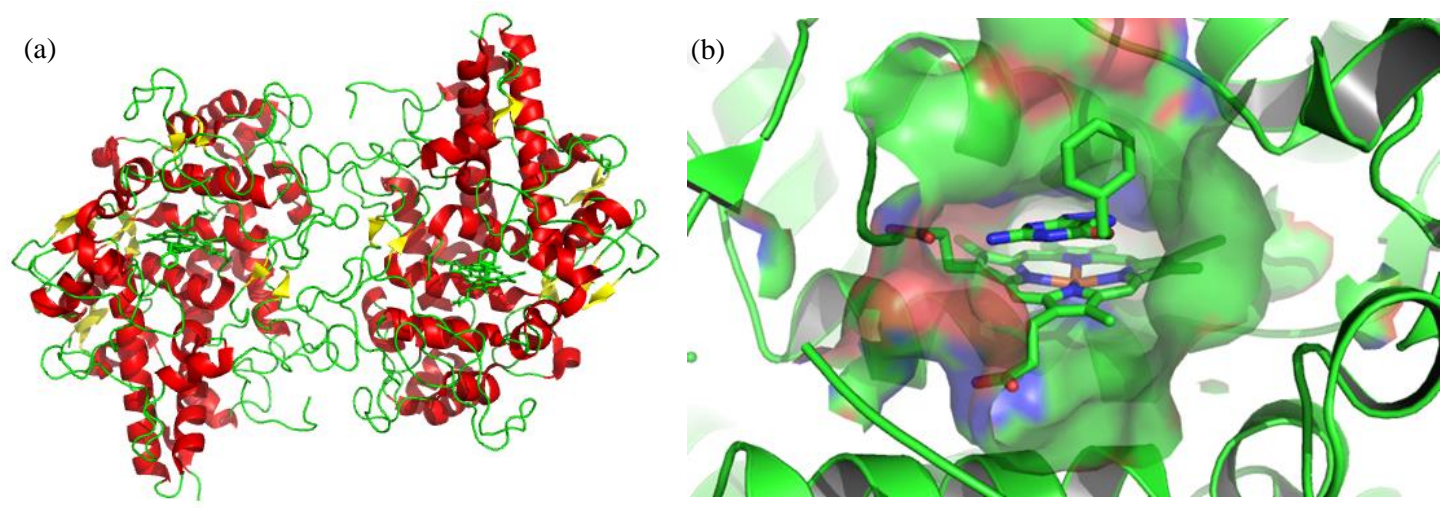

Figure S1 (a) Crystal structure of MPO dimer; (b) Interactions between substrate and MPO receptor.

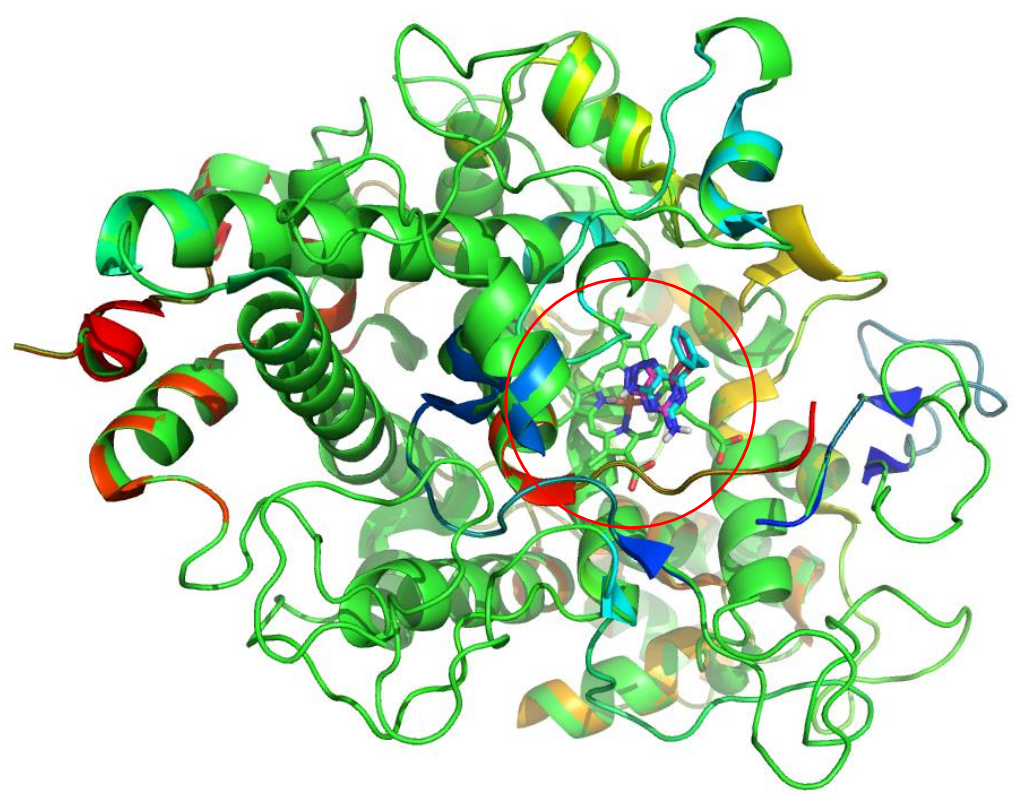

Figure S2 Substrate docking conformation overlap with crystal structure (blue represents the configuration of substrate, red represents calculated docking results). 


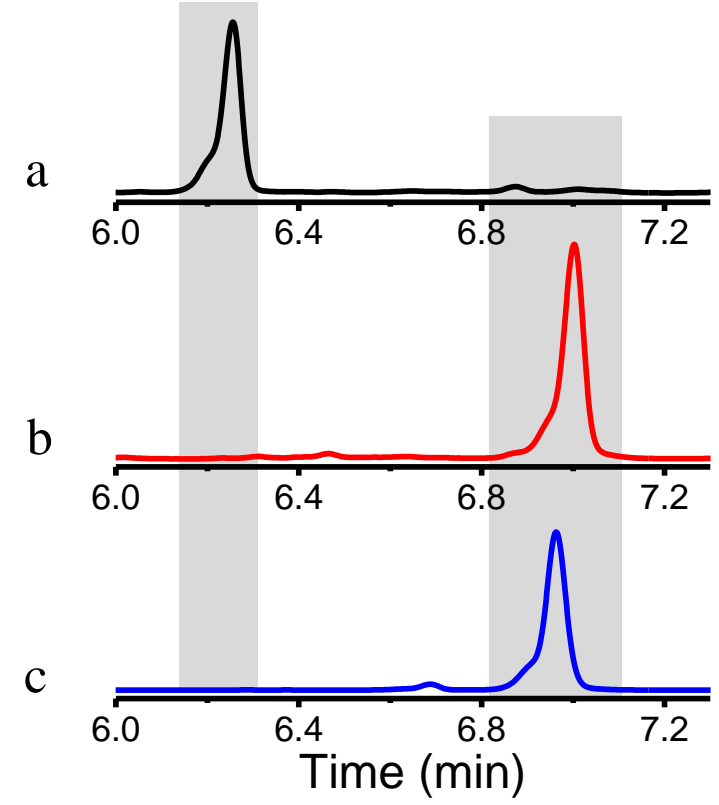

Figure S3 HPLC analysis of the aqueous solution from (a) $10 \mu \mathrm{M}$ FD-301, (b) $10 \mu \mathrm{M}$ FD-301 + $30 \mu \mathrm{M} \mathrm{HOCl,} \mathrm{(c)} \mathrm{methylene} \mathrm{blue}(254 \mathrm{~nm})$.

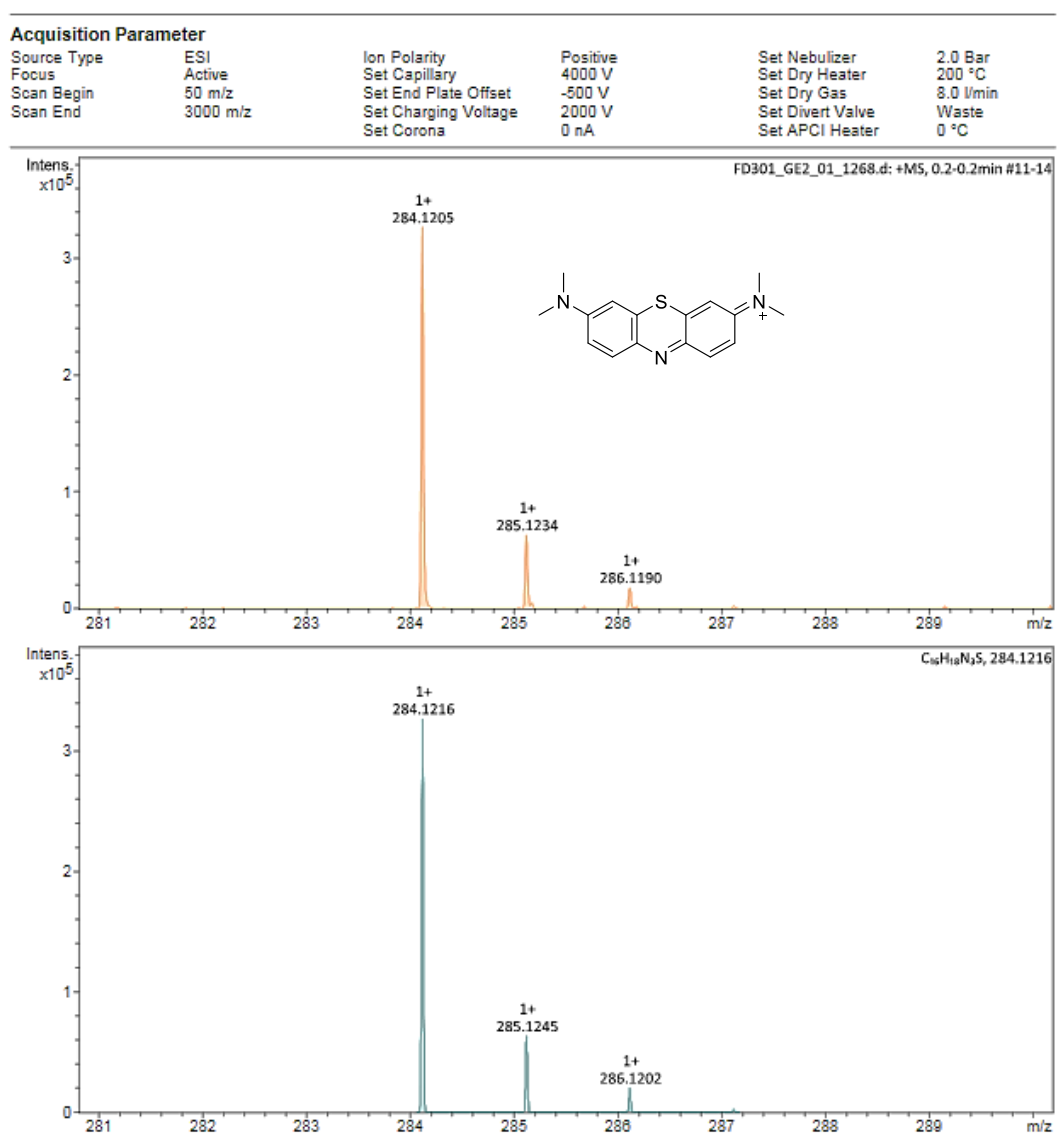

Figure S4 HR-MS of MB produced by the reaction of FD-301 with HOCl (HR-MS 
(ESI): [M - $\left.\mathrm{Cl}^{-}\right]^{+}$calcd for $\mathrm{C}_{16} \mathrm{H}_{18} \mathrm{~N}_{3} \mathrm{~S}^{+}$: 284.1216; found: 284.1216).

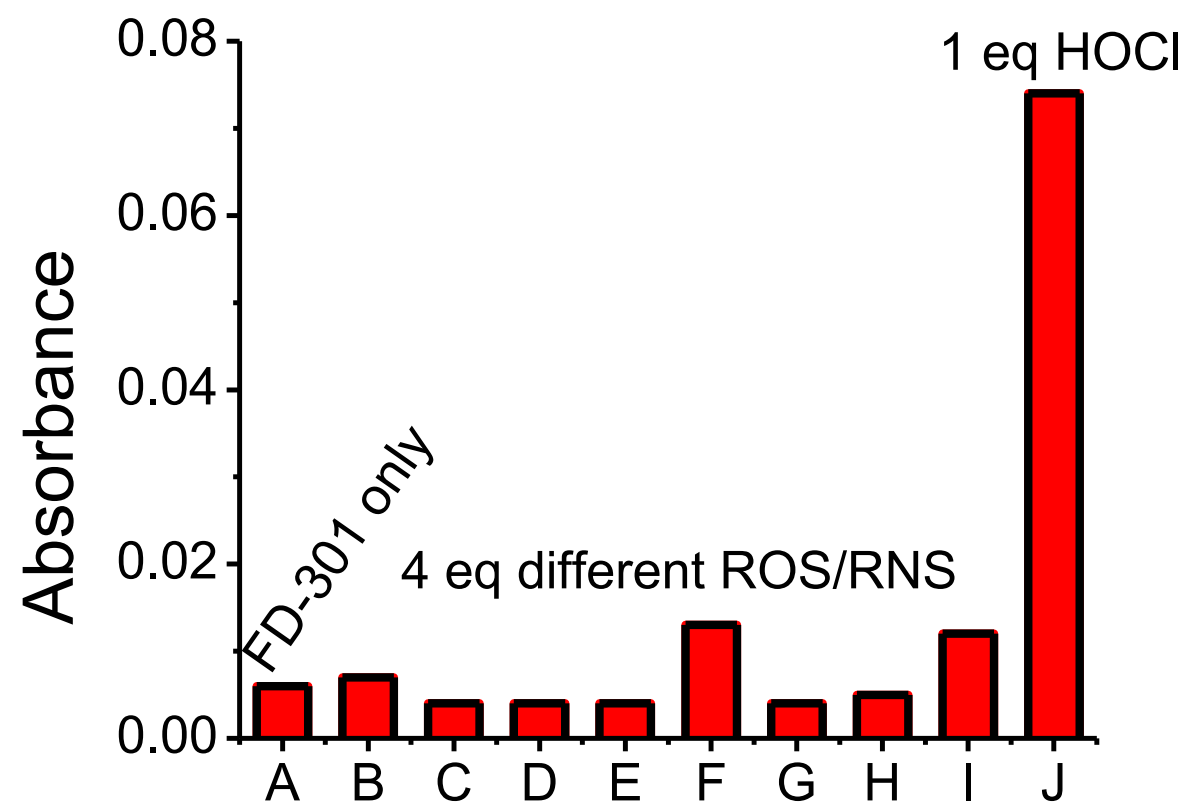

Figure S5 Absorbance of FD-301 at $664 \mathrm{~nm}(5 \mu \mathrm{M})$ after adding various ROS/RNS (from $\mathrm{B}$ to $\mathrm{I}: \mathrm{H}_{2} \mathrm{O}_{2}, \mathrm{TBHP}, \mathrm{O}_{2}^{-}$, $\mathrm{NO},{ }^{\circ} \mathrm{OH}, \mathrm{ONOO}^{-}, \mathrm{ROO}^{\bullet}$ and $t$-BuOO${ }^{\bullet}$ with concentrations of $20 \mu \mathrm{M}$, and $\mathrm{J}$ : $\mathrm{HOCl}$ with a concentration of $5 \mu \mathrm{M}$.

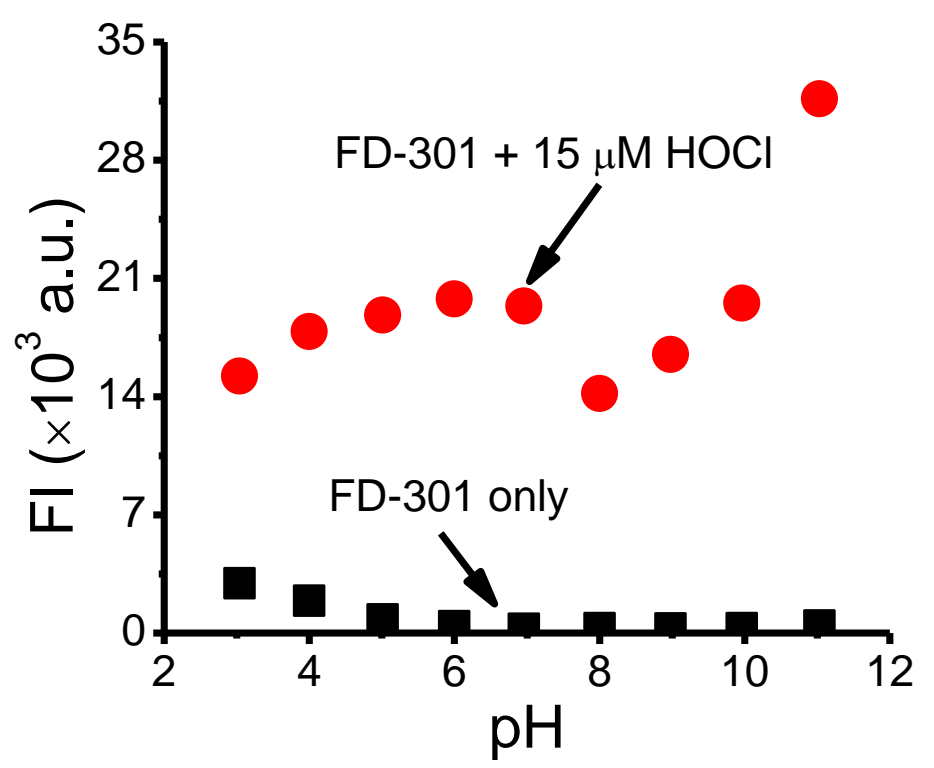

Figure S6 Fluorescence intensity changes of FD-301 $(5 \mu \mathrm{M})$ at $686 \mathrm{~nm}$ with different $\mathrm{pH}$ before and after treated with $15 \mu \mathrm{M} \mathrm{HOCl}$. 


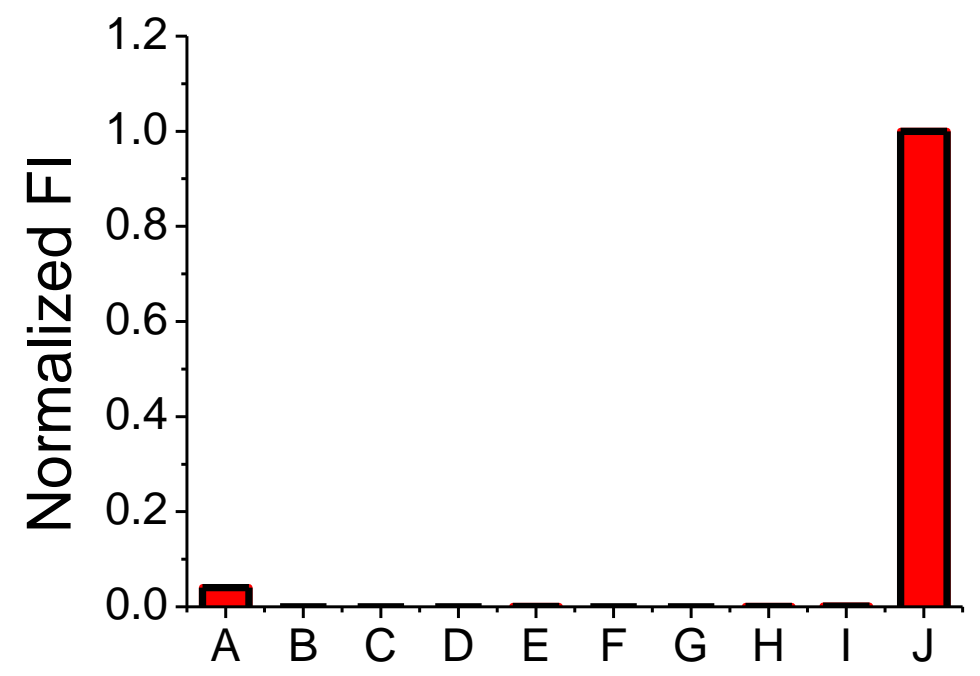

Figure S7 Fluorescence intensity of FD-301 (5 $\mu \mathrm{M}$ in $10 \mathrm{mM}$ PBS, pH 4.52) at $686 \mathrm{~nm}$ after adding various ROS/RNS (from (A) to (J): only FD-301, $\mathrm{H}_{2} \mathrm{O}_{2}, \mathrm{O}_{2}{ }^{-}, \mathrm{NO}, \mathrm{OH}$, $\mathrm{ONOO}^{-}, \mathrm{ROO}$, TBHP, t-BuOO with concentrations of $20 \mu \mathrm{M}$ and $\mathrm{HOCl}$ with a concentration of $15 \mu \mathrm{M}$. $\left(\lambda_{\mathrm{ex}}=620 \mathrm{~nm}\right)$

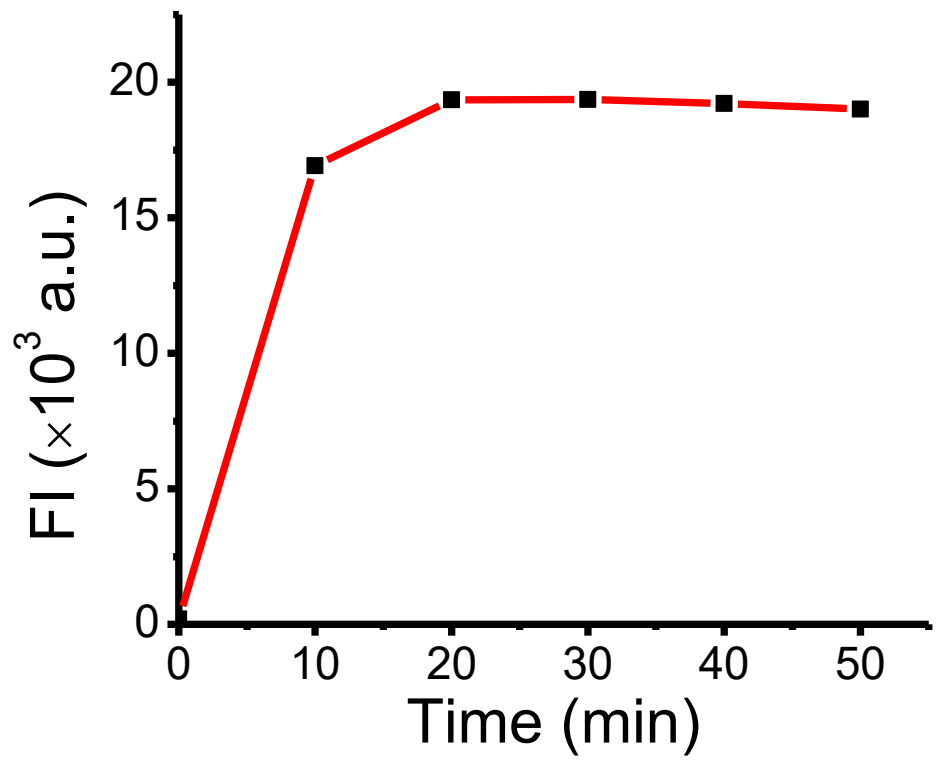

Figure S8 Time-dependent changes in the fluorescence intensity of FD-301 $(5 \mu \mathrm{M})$ in the presence of $50 \mathrm{mU} / \mathrm{mL}$ MPO and $136 \mathrm{mM} \mathrm{NaCl}$ after adding $10 \mu \mathrm{M} \mathrm{H}_{2} \mathrm{O}_{2}$. 


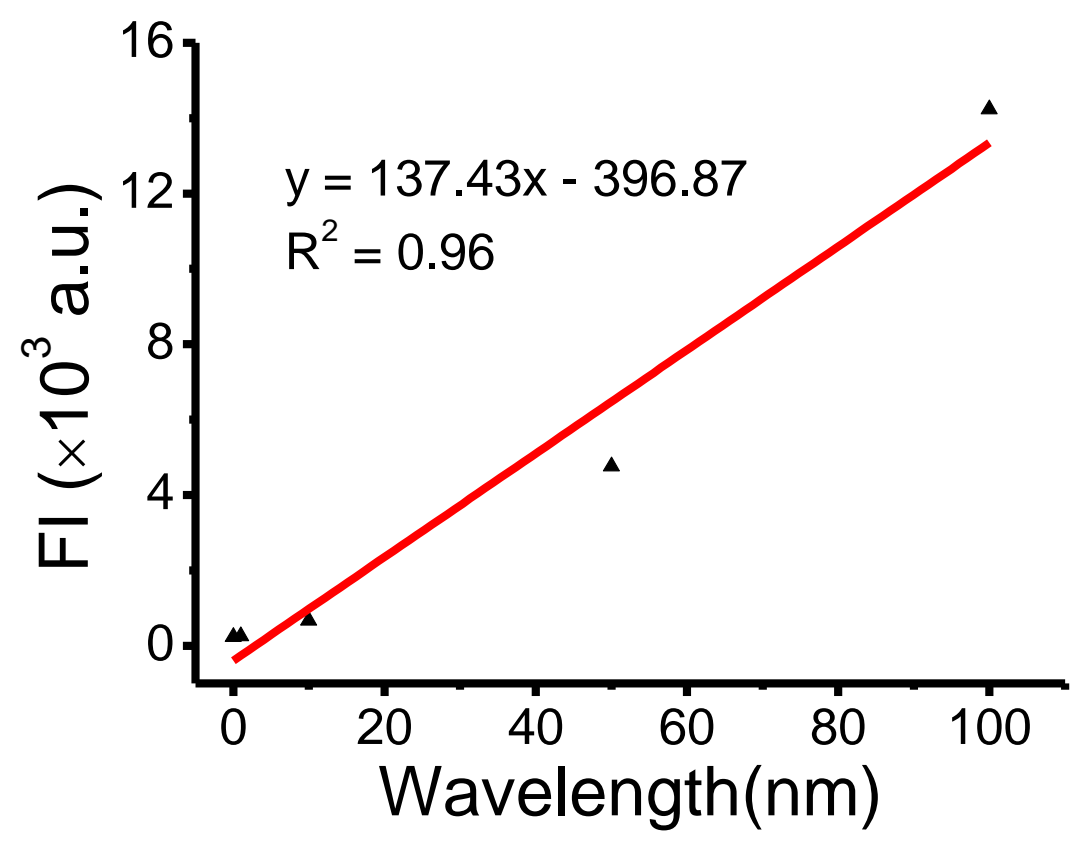

Figure S9 The linear relationship between the fluorescence intensity and the different concentrations of MPO at the range of $0,1,10,50$, and $100 \mathrm{mU} / \mathrm{mL}\left(\lambda_{\mathrm{em}}=686 \mathrm{~nm}\right)$.

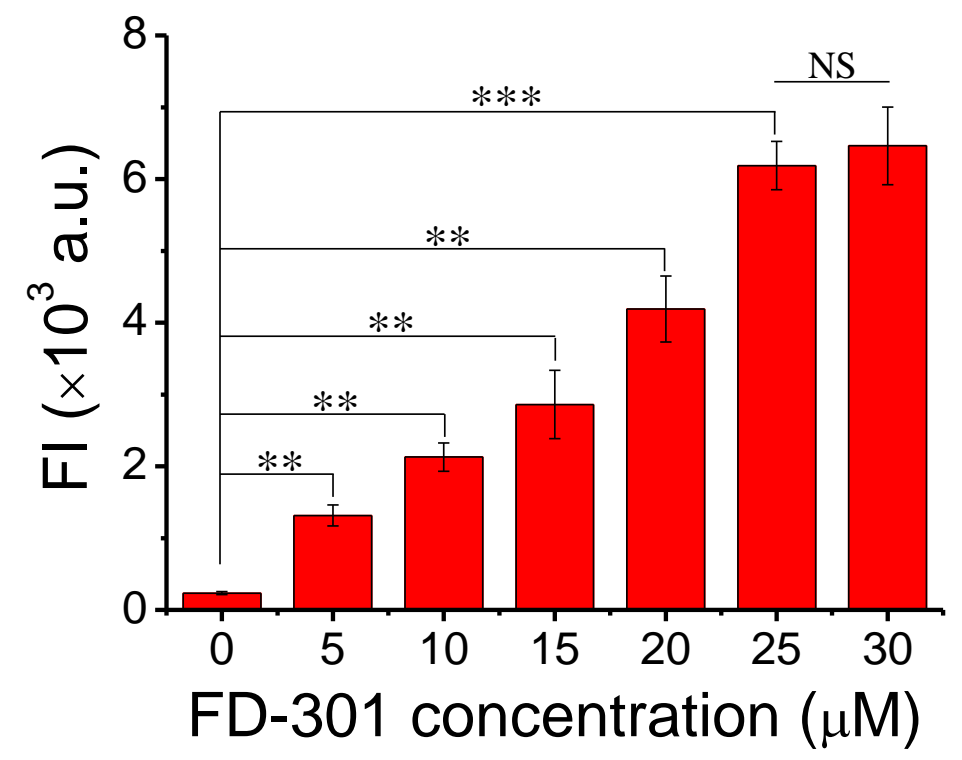

Figure S10 Fluorescence intensity of different concentrations of FD-301 (10 mM PBS, $\mathrm{pH}$ 7.2) in the presence of $10 \mathrm{mU} / \mathrm{mL}$ MPO and $10 \mu \mathrm{M} \mathrm{H}_{2} \mathrm{O}_{2}$. Values are the mean \pm s.d. for $\mathrm{n}=3, * * p<0.01, * * * p<0.001$, NS: not significant $\left(\lambda_{\mathrm{ex}}=620 \mathrm{~nm}\right)$. 


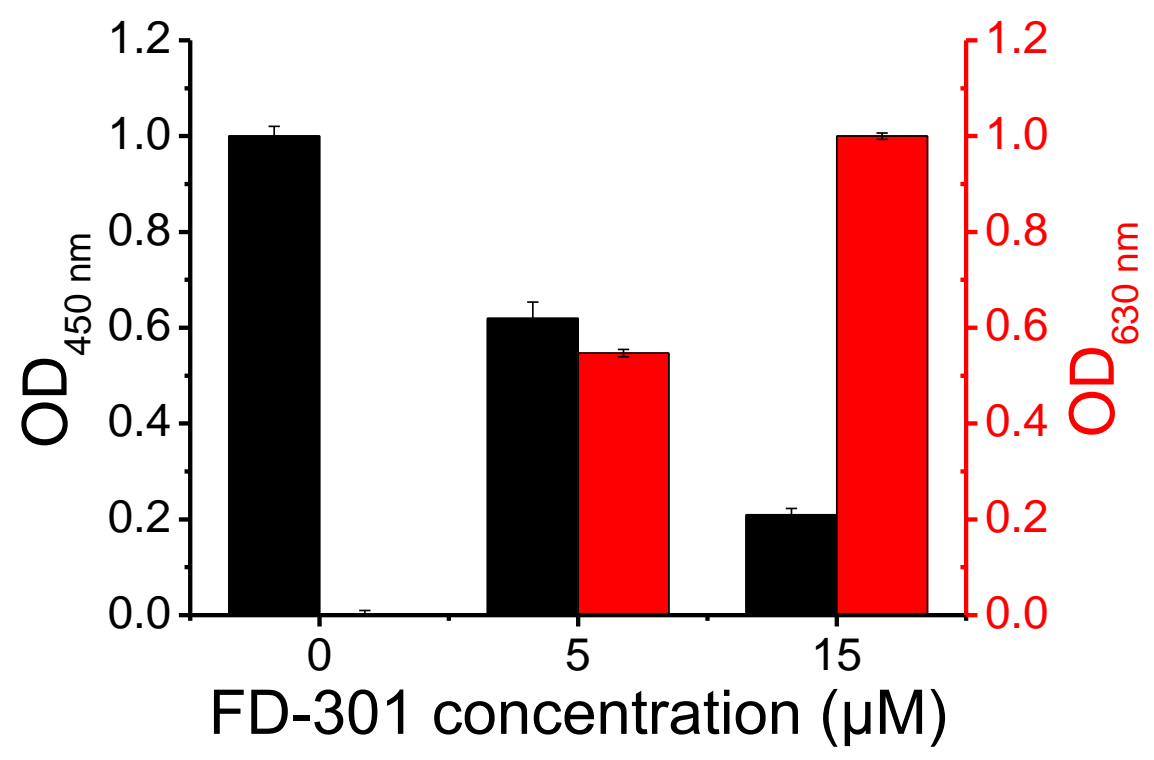

Figure S11. Absorption intensity change at $450 \mathrm{~nm}$ and $630 \mathrm{~nm}$ of different concentrations of FD-301 (10 mM PBS, pH 7.2) in the presence of $50 \mathrm{mU} / \mathrm{mL} \mathrm{MPO}$ and $200 \mu \mathrm{L}$ TMB. Values are the mean \pm s.d. for $\mathrm{n}=3$.
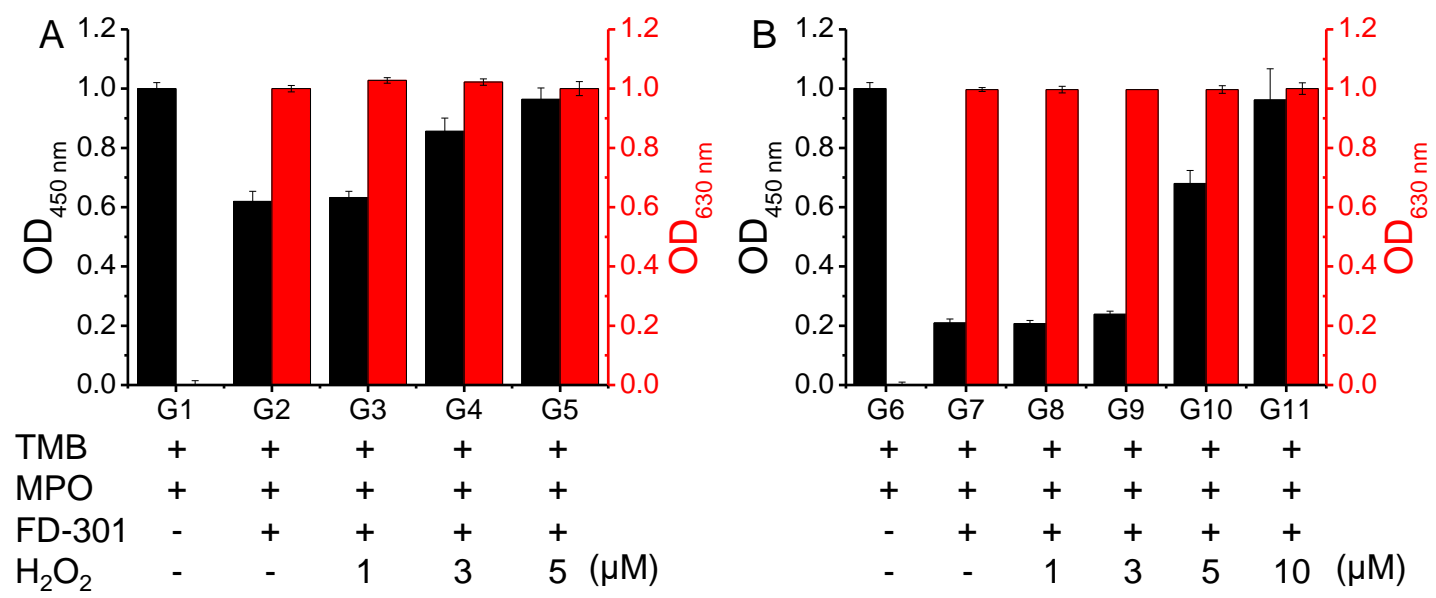

Figure S12. Absorption intensity change of different concentrations of FD-301 (A: 5 $\mu \mathrm{M}$; B: $15 \mu \mathrm{M}$ ) in the presence of $50 \mathrm{mU} / \mathrm{mL}$ MPO and $200 \mu \mathrm{L}$ TMB with additional different concentrations of $\mathrm{H}_{2} \mathrm{O}_{2}$ (G1-G11 represent different groups). Values are the mean \pm s.d. for $\mathrm{n}=3$. 


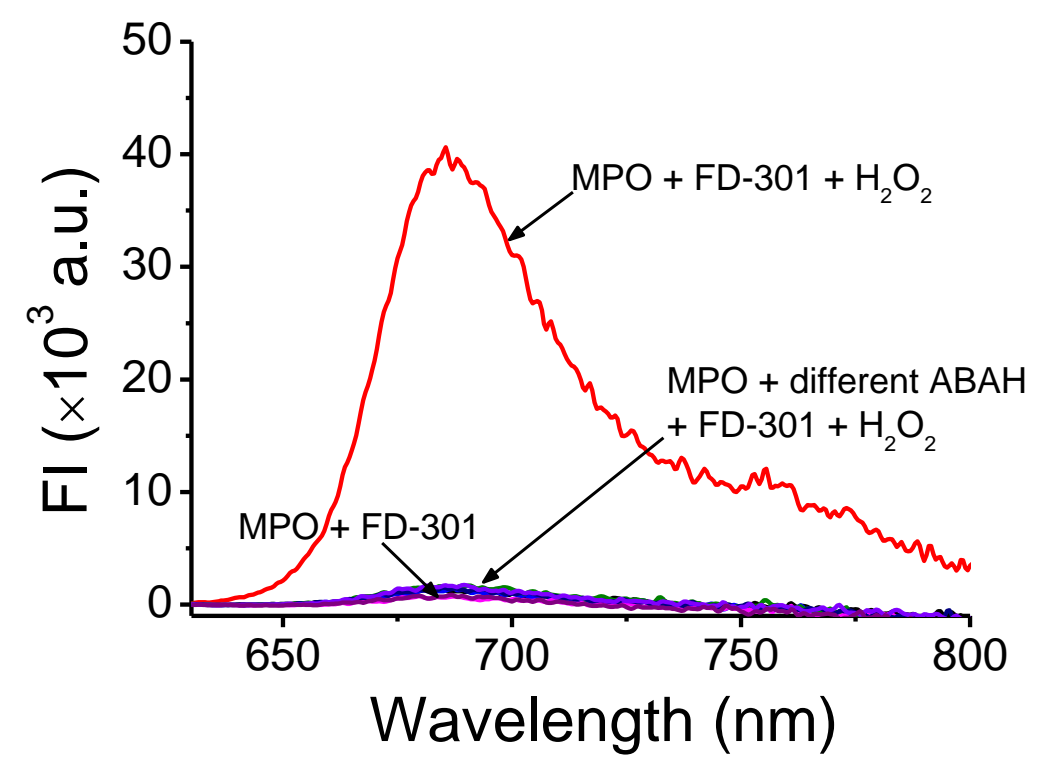

Figure S13 Fluorescence spectra of FD-301 (5 $\mu \mathrm{M}$ in $10 \mathrm{mM}$ PBS, pH 7.2) react with $50 \mathrm{mU} / \mathrm{mL} \mathrm{MPO}$ and $10 \mu \mathrm{M} \mathrm{H}_{2} \mathrm{O}_{2}$ in the presence of different concentrations of $\mathrm{ABAH}$ $(0,10,25,50,100,250$ and $500 \mu \mathrm{M})$.

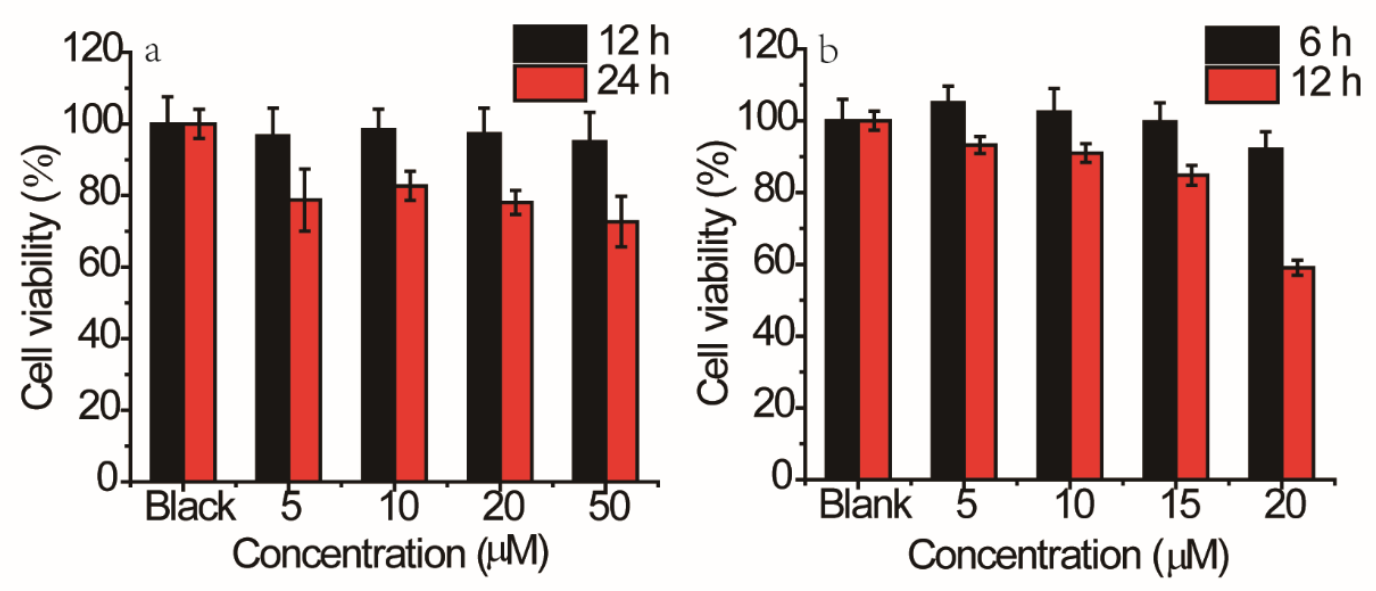

Figure S14 The cell viability of FD-301 at different concentration $(0,5,10,20,50 \mu \mathrm{M})$ (a) in RAW264.7 macrophages cells for $12 \mathrm{~h}$ (black) and $24 \mathrm{~h}$ (red) measured by MTT assay and (b) in HL-60 cells for 6 h (black) and 12 h (red) measured by CCK-8 assay. 


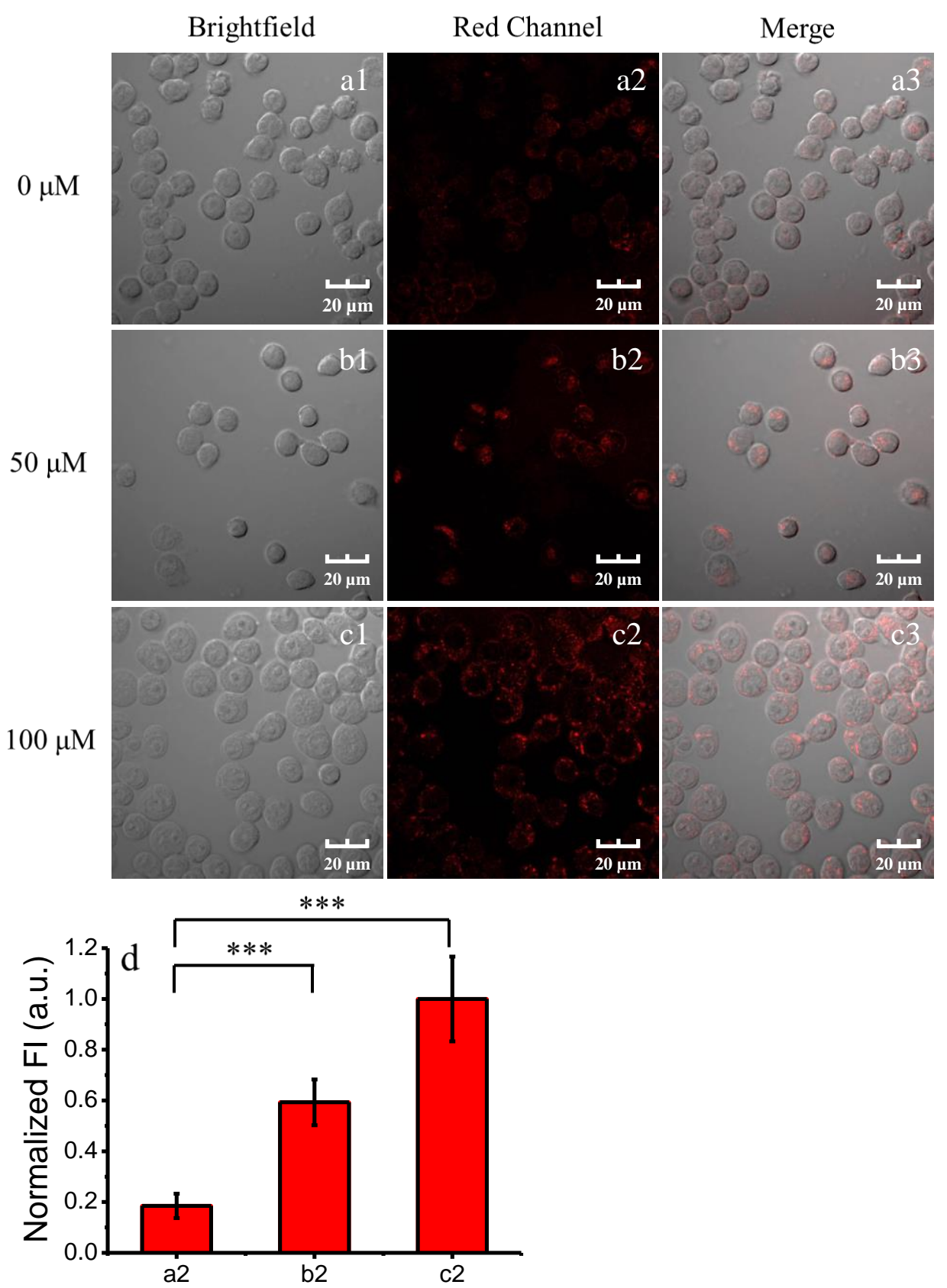

Figure S15 CLSM images of live RAW264.7 macrophages. (a1, a2, a3) Cells were incubated with FD-301 $(10 \mu \mathrm{M})$ for $30 \mathrm{~min}$ and washed by PBS buffer. Cells were preincubated with FD-301 $(10 \mu \mathrm{M})$ for 30 min, washed by PBS buffer and incubated with $\mathrm{HOCl}(50 \mu \mathrm{M}: \mathrm{b} 1, \mathrm{~b} 2, \mathrm{~b} 3 ; 100 \mu \mathrm{M}: \mathrm{c} 1, \mathrm{c} 2, \mathrm{c} 3)$ for $15 \mathrm{~min}$. (d) Fluorescence intensity output of group (a2, b2 and c2). CLSM imaging was performed on an Olympus FV1000 confocal scanning system with a $60 \times$ oil-immersion objective lens for cells. Red channel: $700 \pm 50 \mathrm{~nm}, \lambda_{\mathrm{ex}}=633 \mathrm{~nm}$. Values are the mean \pm s.d. for $\mathrm{n}=$ $15, * * * \mathrm{p}<0.001$. 


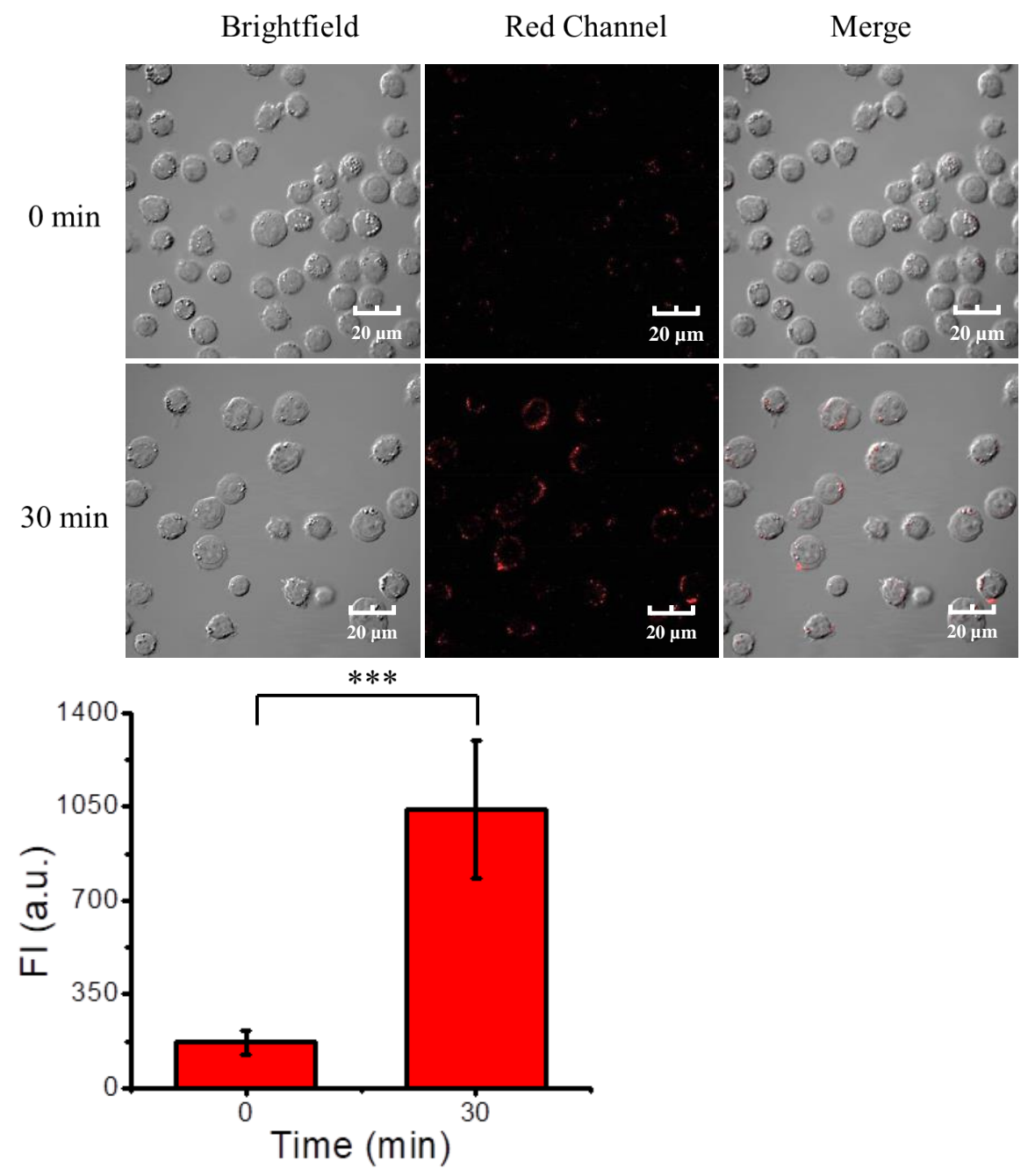

Figure S16 CLSM images of live HL-60 cells incubated with FD-301 (10 $\mu \mathrm{M})$ for different time without any external stimulation. CLSM imaging was performed on an Olympus FV1000 confocal scanning system with a $60 \times$ oil-immersion objective lens for cells. Red channel: $700 \pm 50 \mathrm{~nm}, \lambda_{\mathrm{ex}}=633 \mathrm{~nm}$. Values are the mean \pm s.d. for $\mathrm{n}=$ $15, * * * \mathrm{p}<0.001$ 

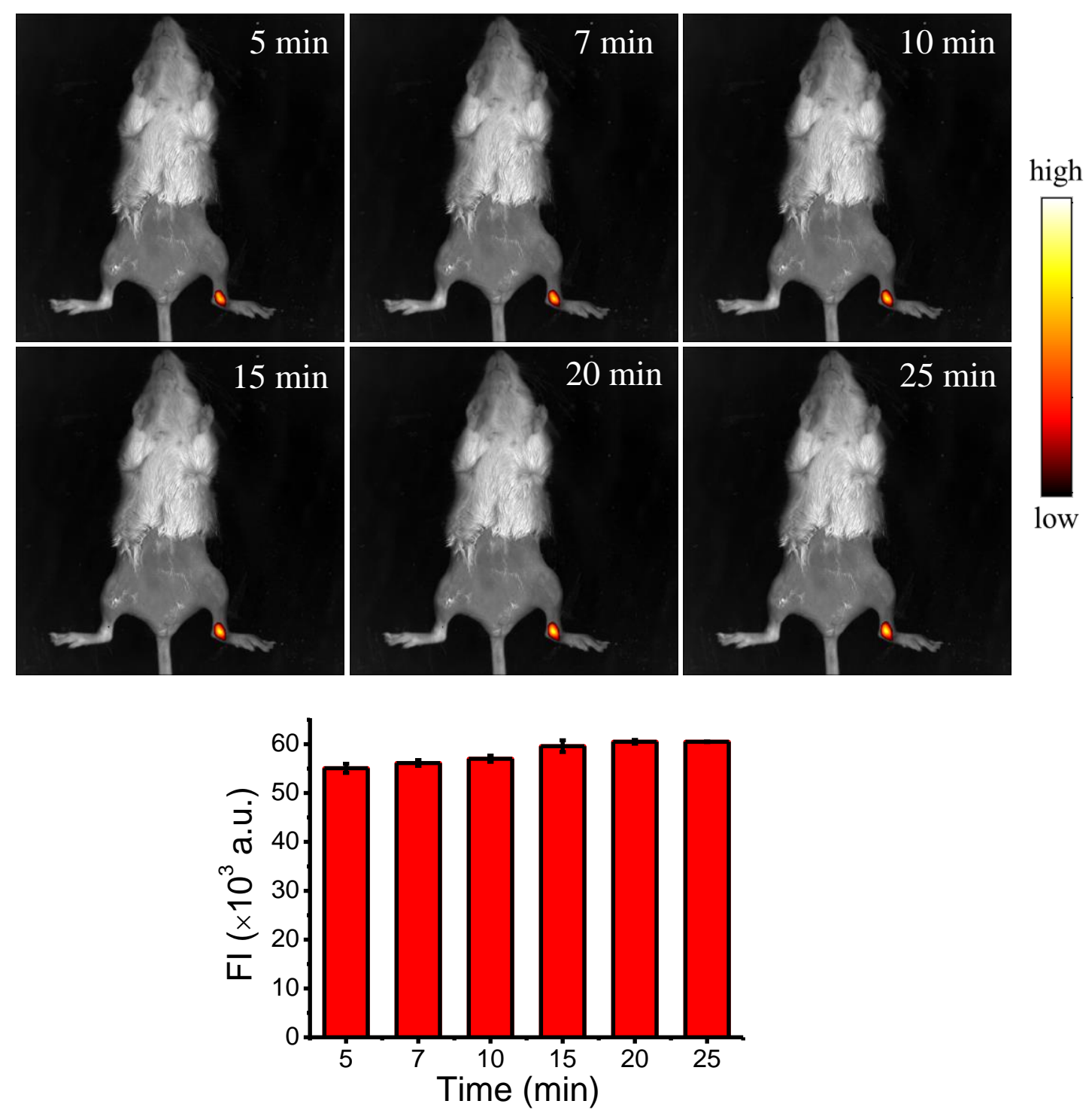

Figure S17 In vivo imaging of the mouse arthritis model after injected FD-301 for different times. (Arthritis model was induced by injecting $100 \mu \mathrm{L} \lambda$-carrageenan, 5 $\mathrm{mg} / \mathrm{mL}$ in PBS into the right tibiotarsal ankles; the left tibiotarsal ankles as the control group without jnjection of $\lambda$-carrageenan; the fluorescence signal was collected at $\lambda_{\mathrm{em}}$ $=720 \pm 60 \mathrm{~nm}$ under excitation with a Xe lamp; FD-301, $100 \mu \mathrm{L}, 1 \mathrm{mM}$ ) 


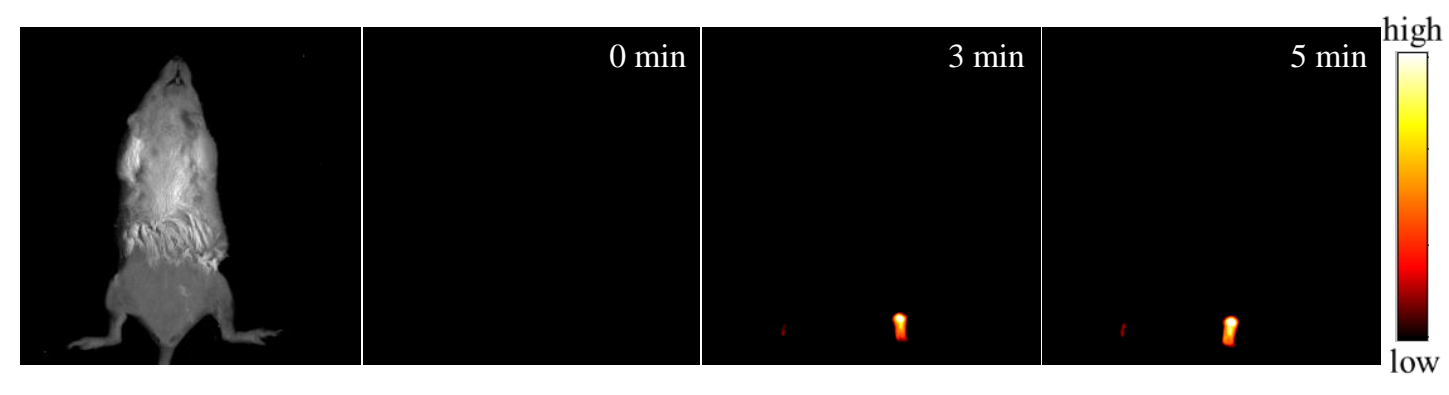

Figure S18 Time dependent fluorescence imaging of the arthritis model after injected FD-301 $(100 \mu \mathrm{L}, 1 \mathrm{mM})$ in both two tibiotarsal ankles and pretreatment of 4-ABAH (500 $\mu \mathrm{M}$ in PBS) only in the left tibiotarsal ankle for $2 \mathrm{~h}$ before incubated with FD-301. Arthritis model was induced by injecting of $\lambda$-carrageenan $(100 \mu \mathrm{L}, 5 \mathrm{mg} / \mathrm{mL})$ in PBS into both two tibiotarsal ankles; the fluorescence signal was collected at $\lambda_{\mathrm{em}}=720 \pm 60$ $\mathrm{nm}$ with a Xe lamp as an excitation source. 


\section{NMR and HR-MS spectra}

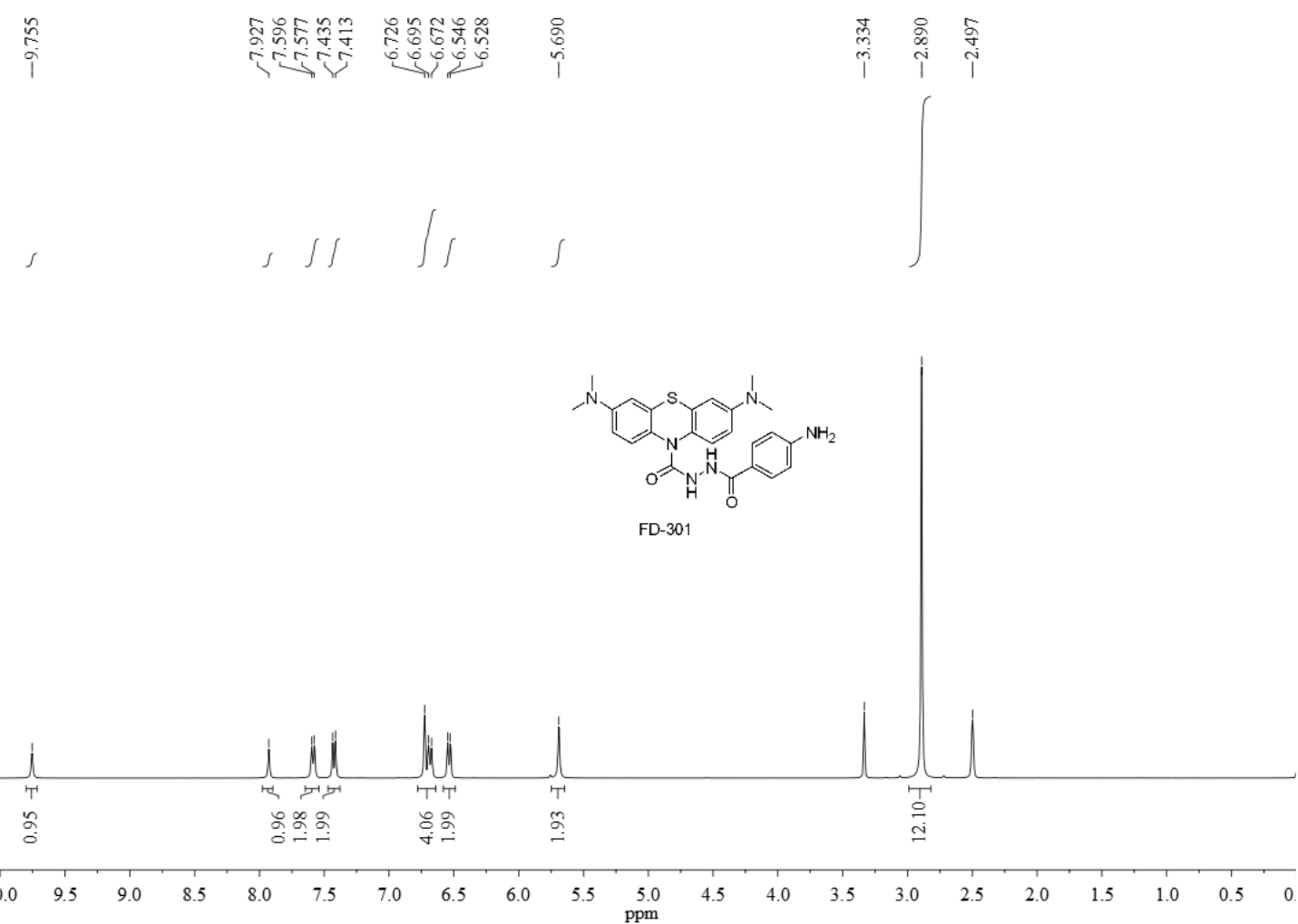

Figure S19 ${ }^{1} \mathrm{H}$ NMR of FD-301 in DMSO- $d_{6}$
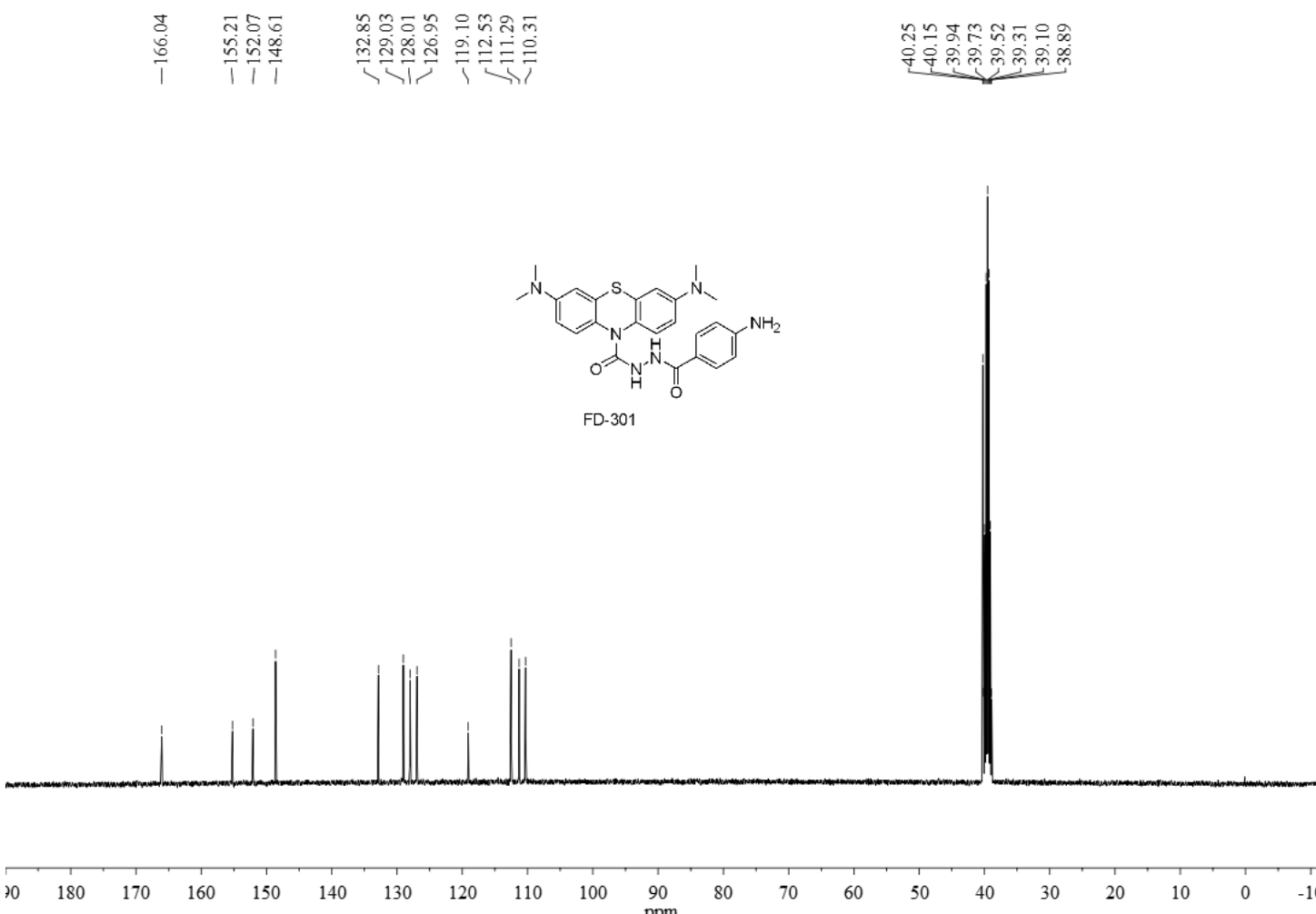

Figure S20 ${ }^{13} \mathrm{C}$ NMR of FD-301 in DMSO- $d_{6}$. 


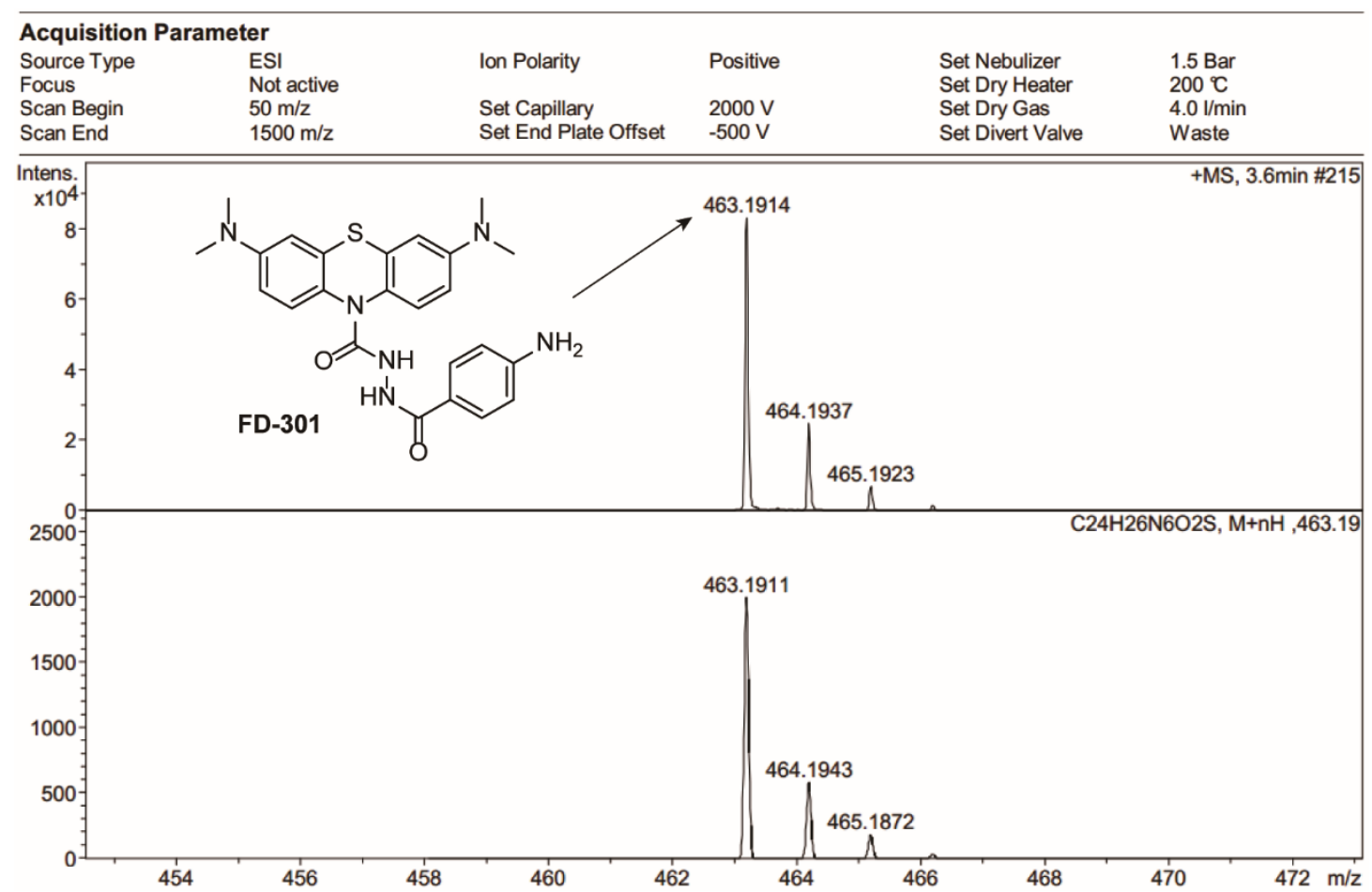

Figure S21 HR-MS of FD-301.

\section{References}

1. Wei, P.; Yuan, W.; Xue, F.; Zhou, W.; Li, R.; Zhang, D.; Yi, T. Chem. Sci. 2018, 9, 495-501.

2. Goiffon, R. J.; Martinez, S. C.; Piwnica-Worms, D. Nat. Commun. 2015, 6, 6271-6279.

3. Gross, S.; Gammon, S. T.; Moss, B. L.; Rauch, D.; Harding, J.; Heinecke, J. W.; Ratner, L.; PiwnicaWorms, D. Nat. Med. 2009, 15, 455-461.

4. Zhang, N.; Francis, K. P.; Prakash, A.; Ansaldi, D. Nat. Med. 2013, 19, 500.

5. Tian, F.; Jia, Y.; Zhang, Y.; Song, W.; Zhao, G.; Qu, Z.; Li, C.; Chen, Y.; Li, P. Biosens. Bioelectron. $2016,86,68-74$.

6. Sun, M.; Yu, H.; Zhu, H.; Ma, F.; Zhang, S.; Huang, D.; Wang, S. Anal. Chem. 2013, 86, 671-677.

7. Shepherd, J.; Hilderbrand, S. A.; Waterman, P.; Heinecke, J. W.; Weissleder, R.; Libby, P. Chem. Biol. 2007, 14, 1221-1231. 